\title{
Biomonitoring of the toxic effects of industrial emissions
}

\author{
Natalia Vasilevskaya*, and Polina Osechinskaya \\ Murmansk Arctic State University, 183038 Murmansk, Russia
}

\begin{abstract}
The article presents results of studying the impact of industrial emissions of the Apatit project (Murmansk region) on the fertility and sterility of pollen of Scotch pine (Pinus sylvestris L.). A low share of fertile pollen $(49.3-57.4 \%)$ and high ratio of sterile pollen (42.6-50.7\%) are revealed in the samples from the city of Apatity under study. The study calculated the palynotoxic effect of the industrial emissions. Shown the toxic effect of emissions of the apatite-nepheline complex on male gametophyte of Scotch pine and the process of gamete formation. The ecological safety of the city of Apatity is closely related to the problems of the complex use of apatite-nepheline ores and the minimization of storage of waste in tailing dumps.
\end{abstract}

\section{Introduction}

The modern concept of sustainable development is based on three important constituents: economic, social and environmental. The main goal of sustainable development in the field of ecology is the stability of ecological systems, especially under conditions of increasing chemical pollution caused by anthropogenic factor. One of the conditions required to maintain the environmental sustainability of areas with industrial impact is the assessment of the state of the environment.

The industry of the Arctic zone of Russia is mainly focused on the use of natural mineral resources. In the Murmansk region, it is based on the mining complex, which includes enterprises of the extractive, metallurgical, mining and chemical industries Most extensively mined are copper-nickel, apatite-nepheline, apatite-magnetite, iron and rare metal ores. The Apatit project is one of the largest producers of phosphate raw materials for the production of mineral fertilizers (the world $3^{\text {rd }}$ largest after China and Morocco) based on the Khibiny deposits of apatite-nepheline ores [1]. The Apatit project is located in the central part of the Kola Peninsula, in the vicinity of the cities of Apatity and Kirovsk, and includes: 4 mines, concentration plants (ANOF-2 and ANOF-3), a tailing dump and number of workshops. Processing of apatite and nepheline concentrates is carried out outside the Murmansk region.

In the process flow design of mining and processing enterprises, which develop deposits of apatite-nepheline ores, tailings dumps are the most environmentally hazardous facilities [2]. The ANOF-2 tailing dump is one of the largest in Russia in terms of area and volume, it receives the flotation tailings of apatite-nepheline ores and ash from the Apatit Thermal

*Corresponding author: n.v.vasilevskaya@gmail.com 
Power Plant. The joint storage of these two wastes contradicts the legislative and traditional practice of mining and chemical industries in Russia [3]. At the same time, the stored waste belongs to the hazard class $\mathrm{V}$ - practically non-hazardous waste [4]. More than 6 million $\mathrm{m}^{3}$ of tailings are supplied to the tailings dump annually. The apatite-nepheline ore concentration wastes consist of a fine fraction of nepheline sands. Under strong winds, dry sands transform into an aerosol state and form dust clouds [5]. The greatest pollution is caused by dusting of the beach areas of the tailing dump, where areas with a particle size of $0.08 \mathrm{~mm}$ are formed, which are transported to distances as long, as 15 kilometers or more. Intense dust removal from the surface of tailing dumps, water and wind erosion of dumps, as well as long-distance transport of aerosols from the metallurgical industry of the Kola Peninsula are the factors forming a vast technogenic geochemical province. The main pollutants entering the environment are strontium, zinc, phosphorus, calcium, sodium, potassium, aluminum, nitrogen and iron containing compounds [1].

The city of Apatity $\left(67^{\circ} 34^{\prime} \mathrm{N}, 33^{\circ} 24^{\prime} \mathrm{E}\right)$ is located in the subzone of north-taiga forests beyond the Arctic Circle, in the foothills of the Khibiny Mountains. The apatite-nepheline concentration plant ANOF-2 and the tailing dump have the greatest negative impact on the environment of Apatity. Soil pollution in the Apatit project's industrial impact zone (including residential area of the city of Apatity) has the character of a technogenic geochemical anomaly with the prominent role of sulfates, nickel, copper, lead, strontium and other metals [6]. The atmospheric air in the city of Apatity, notwithstanding the fact that the Apatit project utilizes highest degree of purification in the Murmansk region, is polluted with dust, which contains toxic compounds [7].

In conditions of increasing chemical pollution of the environment of industrials cities, of particular relevance is the assessment of the effect of pollutants on biota. Environmental stress causes disturbances of microgametogenesis in higher plants, which manifests itself in an increased production of sterile pollen [8]. The use of palynological analysis reveals the presence of gametopathogenic compounds in the environment. Applicability of pollen for detecting the phytotoxic and mutagenic effects of pollutants is caused by its sensitivity to exposure of pollutants. It is just in the haploid state that lethal mutations occur during the formation of pollen grains [9].

\section{Materials and methods}

The object of the research is Pinus sylvestris L. (Scots pine). P. sylvestris is widely spread in a number of cities of the Murmansk region, dominating in natural green spaces in Monchegorsk and Polyarnye Zori [10]. In the city of Apatity, it predominantly grows in the forest park zones on the outskirts of the city. In May 2020, four test sites were laid in the industrial impact zone of the Apatit project: $\mathrm{P}_{1}$ - Tailing Dump, it is located in the southeast direction, $2 \mathrm{~km}$ from the center of the Tailing dump of ANOF-2. $\mathrm{P}_{2}-$ ANOF-2, the forest cenosis in $1 \mathrm{~km}$ from the center of ANOF-2 in the southeast direction. $\mathrm{P}_{3}-$ Kozlova Street, the recreation forest zone on the northern outskirts of Apatity, 30-35 m from the railway and $3.8 \mathrm{~km}$ from the center of ANOF-2. $\mathrm{P}_{4}$ - «Lyubkino Swamp», the recreation forest zone on the southeastern outskirts of the city of Apatity, $5.7 \mathrm{~km}$ from the center of the ANOF-2. It is unique natural site on the territory of which 11 species of orchids (Cypripedium calceolus, Platanthera bifolia, Coeloglossum viride, etc.) grows, that are included in the Red Data Book of the Murmansk Region and the Red Data Book of Eastern Fennoscandia [11]. The control site is established in the settlement of Verkhnetulomsky, $70 \mathrm{~km}$ south-west of Murmansk, $130 \mathrm{~km}$ from the ANOF-2. There are no environmentally hazardous industrial facilities in the territory of the settlement and in its vicinity.

In late June samples of matured pollen of P. sylvestris were collected. A joint sample from each site was collected from five typical trees, seven microstrobiles were picked from 
each tree $(\mathrm{N}=35)$. Male cones were dried and fixed in $40 \%$ alcohol solution. The collected material was stored in a refrigerator at $0-4^{\circ} \mathrm{C}$. For pollen analysis, microsporophylls from the middle part of microstrobile were used; pollen was stained with Lugol's solution. Fertile pollen is stained, sterile pollen is not (figure 1).

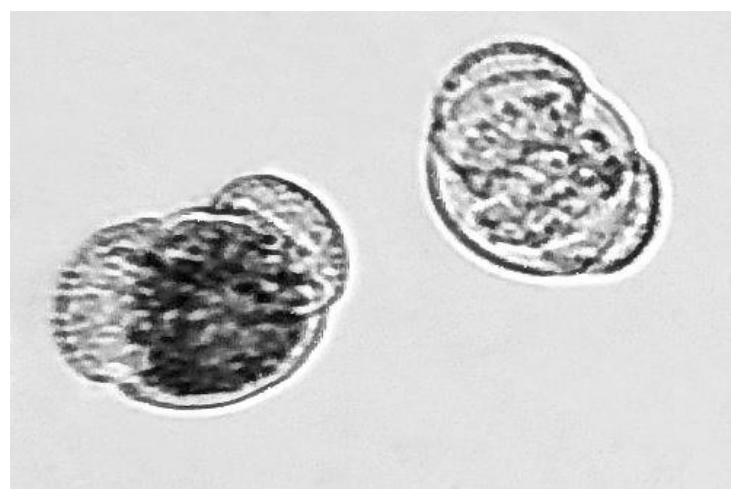

Fig. 1. Fertile and sterile pollen grains of Pinus sylvestris.

The studies were carried out using light microscopy (magnification 200 times). Pollen analysis was carried out on the basis of micrographs taken through the eyepiece of a microscope with a 13 megapixel Xiaomi Redmi Note 5A Prime camera. In each sample, fertile and sterile pollen grains $(\mathrm{N}=550)$ were counted from good quality photographs. Then sterility index (IS) was calculated, which shows how many times the frequency of the induced level of sterility caused by contamination of environment is higher than the level of spontaneous sterility (in the control sample) [12]. The palynotoxic effect of apatite-nepheline emissions - PE (in \%) was calculated using the formula of I. N. Lozanovskaya [13], modified by E. E. Ibragimova [14] for the analysis of male gametophyte of plants in terms of pollen fertility and was calculated according to the formula 1 :

$$
P E=\frac{F_{o}-F_{x}}{F_{o}} \cdot 100,
$$

where Fo is an intense indicator of the value of the spontaneous fertility of pollen of control plants, Fx is an intense indicator of the value of the induced fertility of pollen of plants under study. The palynotoxic effect shows by how many percent the fertility level in the test sample (induced fertility) is lower than the pollen fertility in the control (spontaneous fertility) taken as $100 \%$ [15].

\section{Results}

As a result of the research, it is found that the proportion of fertile pollen of P. sylvestris in the control is $70.2 \%$. Low fertility is a distinctive feature of hybrid forms, which often include the northern form of Scots pine. In the city of Apatity and its vicinity, the fertility of pine pollen is much lower and varies from 49.3 to $57.5 \%$ (figure 2 ; table 1 ). The minimum content of fertile pollen grains is found in the samples from Kozlov Str. and the Tailings dump (figure 2). In samples from the vicinity of the apatite-nepheline concentration plant ANOF-2 and «Lyubkino Swamp», the ratio of pollen grains that retained the genetic material is 57.5 and $55.1 \%$, respectively.

The reproductive system of $P$. sylvestris reacts to technogenic pollution by increasing of the amount of sterile pollen grains. Colorless pollen grains are indicators of abortive pollen (figure 1). The content of sterile pollen of Scotch pine in the control sample is $29.8 \%$ 
(Verkhnetulomsky settlement), despite the absence of environmentally hazardous objects in the settlement and the remoteness from mining centers (figure 2). This also is indicative of the long-range atmospheric transport of aerosols from the industrial centers of the Kola Peninsula and high sensitivity of pine to environmental pollution.

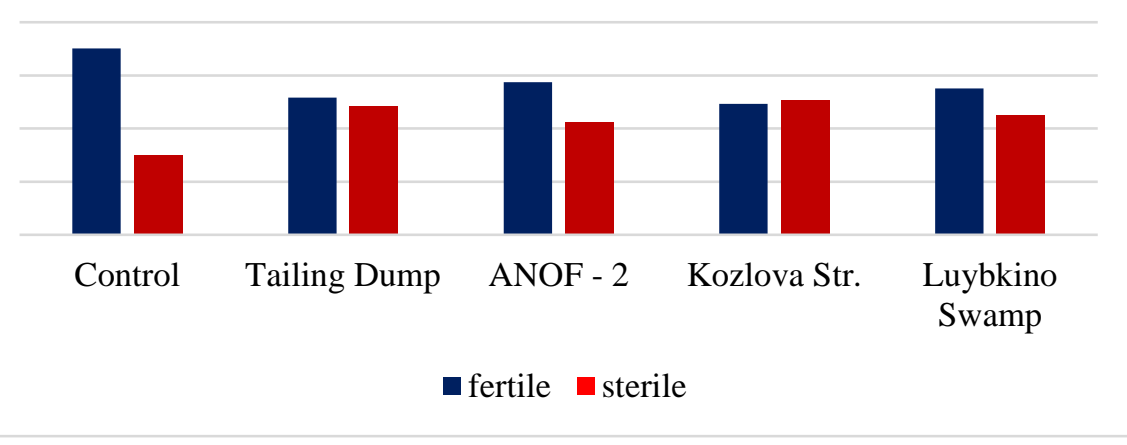

Fig. 2. The ratio of the number of fertile and sterile pollen grains of Pinus sylvestris in Apatity (in \%).

In the zone of industrial impact of the Apatit project the highest values of sterility of male gametophyte of $P$. sylvestris are found on the northern outskirts of Apatity (Kozlova Str. $50.7 \%$ ) and the Tailing dump (48.4\%) (figure 2; table 1). In the samples from the «Lyubkino Swamp» test plot and the vicinity of ANOF-2, the share of abortive pollen is less (figure 2). Studies show that under the influence of emissions of Apatit Project a lot of dwarf pollen grains are formed, such grains being usually sterile and degenerate even before the formation of sperm, and as a result these pollen grains become empty.

Table 1. Content of fertile and sterile pollen of Pinus sylvestris in the samples from industrial pollution sites, city of Apatity.

\begin{tabular}{|c|c|c|c|c|c|c|}
\hline Control & $\begin{array}{l}\text { Tailing } \\
\text { Dump }\end{array}$ & \multicolumn{2}{|c|}{ ANOF-2 } & \multicolumn{2}{|c|}{$\begin{array}{l}\text { Kozlova } \\
\text { r. Swamp }\end{array}$} & Lyubkino \\
\hline Number of fertile $p$ & pollen 386 & 284 & & 16 & 271 & 303 \\
\hline Number of sterile $p$ & pollen 164 & +266 & & 34 & 279 & 247 \\
\hline Sterility index & $-\quad 1.6$ & 1.4 & 1.7 & 1. & & \\
\hline $\begin{array}{l}\text { Palynotoxic } \\
\text { effect (in\%) }\end{array}$ & 26.4 & 19.1 & 29.8 & & 21.5 & \\
\hline
\end{tabular}

The calculation of the index of sterility (IS) showed that its value varies from 1.4 to 1.7 (table 1). The index of sterility shows how many times the frequency of the induced sterility, caused by environmental contamination, is higher than spontaneous sterility in the control. The highest values of the index are found in the samples from the Tailing Dump and Kozlov Str. Induced sterility of pollen of Scots pine on these test sites is 1.6-1.7 times (respectively) higher than spontaneous sterility (in control). 
As a result of the calculation of the palynotoxic effect according to E. E. Ibragimova [14], the highest PE indices are found on the Kozlov Str. (29.8\%) and near the Tailing dump $(26.4 \%)$, which indicates the greatest toxic effect of pollutants on pollen fertility (table 1). At the «Lyubkino Swamp» the value of palynotoxic effect is $22 \%$. At the test site ANOF-2, the $\mathrm{PE}$ index is rather low, which, apparently, is associated with the transfer of emissions from the apatite-nepheline concentration plant over long distances.

\section{Discussion}

Studies have shown that emissions from industrial facilities of the Apatit project cause a decreased production of fertile pollen of Scotch pine to $49.3-57.4 \%$. The share of fertile pollen of $P$. sylvestris in the samples from other cities of the Murmansk region is higher than that in the city of Apatity. In the city of Murmansk this indicator varies by city districts from 72 to $89.2 \%$ [16]. In Monchegorsk, the content of fertile pollen of Scotch pine in the samples is $85.2-97.5 \%$ [17], [18].

Under the influence of industrial emissions of the apatite-nepheline complex, the production of sterile pollen of $P$. sylvestris in the city of Apatity and its vicinity significantly increases to $42.6-50.7 \%$. In Murmansk, the ratio of sterile pollen of Scotch pine varies in the samples in various districts of the city from 10.8 to $28 \%$ (in the control $-3.4 \%$ ) [16]. Lower values of the sterility $(3-14.8 \%)$ of the male gametophyte of $P$. sylvestris were also found in Monchegorsk - the center of nonferrous metallurgy of the region [17], [18]. An increase of abortive pollen formation in the city of Apatity are induced by emissions of ANOF-2 and dusting of the Tailings dump. The emissions of Apatit Plant contains such pollutants as strontium, zinc, phosphorus, calcium, sodium, potassium, aluminum, nitrogen compounds and iron. In the cities of Apatity and Kirovsk, the background values for strontium are exceeded by more than 4 times, for copper -2 times, for phosphates -10 times, for sulfates and fluorides -3 times [7]. Apatite-nepheline dust also contains a certain amount of natural radionuclides [1].

Environmental stresses (heat, drought, cold, humidity, pollutants) affect the quality of pollen and its viability, influencing at all stages of its development [19]. Stressful environmental conditions can cause asynchronous processes during the development of the male gametophyte, increasing the amount of abortive pollen. Sterile pollen grains are characterized by deformation and degeneration of nuclei, cytoplasm, or whole cells. The formation of such pollen in plants, as a rule, is associated with disorders during meiosis and microsporogenesis [20]. The behavior of chromosomes during meiosis must be under strict genetic regulation, in order to facilitate correct separation of chromosomes into daughter cells, while abnormal meiosis inevitably causes abortion of pollen [21]. The highest rates of aborted pollen are associated with the highest rates of meiotic disturbances [22]. There are several main reasons for sterility of pollen grains: cytoplasmic male sterility, genetic mutations, chemical castration as a result of exposure to various chemicals on the reproductive system of plants [23]. The presence of sterile pollen directly affects the fertility of the plant, since the lack of normal fertile pollen cannot provide the necessary fertilization in all ovules.

\section{Conclusion}

Pollen sterility under anthropogenic impact is a major environmental problem affecting the productivity of many species of plants. The high sterility and low fertility of pollen of $P$. sylvestris of the city of Apatity indicates the toxic effect of emissions of the apatite-nepheline complex on the male gametophyte and the process of gamete formation. The palynotoxic 
effect, calculated on the base of indices of spontaneous and induced fertility of pine pollen, is the highest on the northern outskirts of the city (Kozlova Str.).

According to the criteria of assessing of the environmental load (morbidity of adults and children, natality, premature mortality), developed by the Ministry of Ecology and Natural Resources of the Russian Federation, the Murmansk Region corresponds to the zone of extreme risk of human ecopathology. The ecological safety of the region is closely related to the problems of the complex use of apatite-nepheline ores and the minimization of storage of waste in tailing dumps.

\section{References}

1. I.P. Karnachev,V.K. Zhirov, O.i. Zagvozdina, M.M. Krymskaya, Vestnik of Murmansk State Technical University, 14, 552 (2011)

2. S.V. Tereshchenko? V.V. Marchevskaya D.N. Pavlishina, Herald of the Kola Science Center RAS, 4, 62 (2016)

3. T.I. Priymak, A.P. Zosin V.A. Masloboev, Ecological Aspects of Hypergenesis of Mineral Raw Materials in the Subarctic (Apatity: Kola Scientific Center of the Russian Academy of Sciences, 2013)

4. Y.R. Timofeeva, Problemy nedropolzovaniya, 2, 147 (2014)

5. Y.R. Timofeeva, E.A. Stepanova, V.L. Bogdanov, Izvestia of Saint - Petersburg State Agrarian University, 42, 294 (2016)

6. V.F. Demin, S.O. Klyuchnikov A.I. Burkin, Russian Bulletin of Perinatology and Pediatrics, 39, 19 (1994)

7. E.L. Vorobievskaya, N.B. Sedova, M.V. Slipenchuk and M.N. Tsymbal, Theoretical and Applied Ecology, 1, 64 (2020)

8. N.V. Vasilevskaya, A.I. Sikalyuk, IOP Conf. Series: Earth and Environmental Science, 677, 052067 (2021)

9. V. Bessonova, L. Fendyur L and T. Peresypkina, Botanicheskii Zhurnal, 82, 38 (1977)

10. O.B. Gontar, E.A. Svyatkovskaya, N.N. Trostenyuk, V.K. Zhirov, ect., Izvestiya of the Samara Scientific Center of RAS, 2 , 70 (2016)

11. I.V. Blinova, Botanicheskii Zhurnal, 94, 212 (2009)

12. D. Emirova, D. Balichieva E. Ibragimova, Ecosystems, their Optimization and Protection, 2, 200 (2010)

13. I.N. Lozanovskaya D.S. Orlov, L.K. Sadovnikova, Ecology and Protection of the Biosphere in Case of Chemical Pollution (Moscow: Higher school, 1998)

14. E.E. Ibragimova, Scientific Notes of the Crimean Engineering and Pedagogical University. Series: Biological Science, 1, 13 (2017)

15. D.E. Emirova, E.E. Ibragimova, Scientific Notes of V I Vernadsky Crimean Federal University Series: Biology and Chemistry, 23, 186 (2010)

16. N.V. Vasilevskaya A.D. Domakhina, Proceedings of Petrozavodsk State University, 4, 139 (2016)

17. N.V. Vasilevskaya, N.V. Petrova, Proceedings of Petrozavodsk State University, 4, 7 (2014)

18. N.V. Vasilevskaya, N.V. Petrova, IOP Conf. Series: Earth and Environmental Science 666, 022072 (2021)

19. E.Pacini, S.R. Dolferu, Frontiers in Plant Science 10, 1 (2019) 
20. L. F. Yandovka, Agrarian Bulletin of the Urals 6, 58 (2010)

21. M. Mwathi, M. Gupta, C. Atri, S. Banga, J. Batley, A. Mason, Theoretical and Applied Genetics 130, 767 (2017)

22. L. C. Saylor, B.W. Smith, American Journal of Botany 53, 45 (1996)

23. Z. Pausheva, Workshop on plant cytology (Moscow: Agropromizdat, 1988) 